Farum

Sociológico

\section{Forum Sociológico}

Série II

28 | 2016

Interculturalidade e educação

\title{
The implications of historical and contemporary anti-Semitism in Glasgow and Scotland for Global Citizenship
}

As implicações do anti-semitismo histórico e contemporâneo em Glasgow e na Escócia para a cidadania global

\section{Stephen McKinney}

\section{OpenEdition}

\section{Journals}

\section{Electronic version}

URL: https://journals.openedition.org/sociologico/1396

DOI: $10.4000 /$ sociologico.1396

ISSN: 2182-7427

Publisher

CICS.NOVA - Centro Interdisciplinar de Ciências Sociais da Universidade Nova de Lisboa

\section{Electronic reference}

Stephen McKinney, "The implications of historical and contemporary anti-Semitism in Glasgow and Scotland for Global Citizenship", Forum Sociológico [Online], 28 | 2016, Online since 31 December 2016, connection on 30 March 2022. URL: http://journals.openedition.org/sociologico/1396 ; DOI: https:// doi.org/10.4000/sociologico.1396 


\title{
THE IMPLICATIONS OF HISTORICAL AND CONTEMPORARY ANTI-SEMITISM IN GLASGOW AND SCOTLAND FOR GLOBAL CITIZENSHIP AS IMPLICAÇÕES DO ANTI-SEMITISMO HISTÓRICO E CONTEMPORÂNEO EM GLASGOW E NA ESCÓCIA PARA A CIDADANIA GLOBAL
}

\author{
Stephen McKinney \\ University of Glasgow, School of Education, Creativity, Culture and Faith (Research and Teaching Group)
}

\begin{abstract}
One of the stated aims of the state-funded school system in Scotland is to help develop global citizens for the future. This paper argues that Global Citizenship must recognize the continued widespread adherence to religion, acknowledge religious diversity and the challenges faced by religious minorities to ensure a more comprehensive education in cultural identity, human rights, diversity and inclusion. The paper uses the example of the Jews in the Greater Glasgow Area and Scotland to illustrate this point. A discussion and analysis of the history and contemporary manifestations of anti-Semitism is used to provide a deeper and more nuanced knowledge and understanding of this form of discrimination.
\end{abstract}

Keywords: anti-Semitism, Glasgow, Scotland, Global Citizenship

\begin{abstract}
Resumo
Um dos objectivos declarados do sistema escolar financiado pelo Estado na Escócia é ajudar a desenvolver cidadãos globais para o futuro. Neste artigo argumenta-se que a Cidadania Global deve reconhecer a contínua adesão generalizada à religião, dar conhecimento da diversidade religiosa e dos desafios enfrentados pelas minorias religiosas para garantir uma educação mais abrangente sobre identidade cultural, direitos humanos, diversidade e inclusão. No artigo é usado o exemplo dos judeus da Greater Glasgow Area e da Escócia para ilustrar este tópico. Para possibilitar um conhecimento e compreensão mais profundos e detalhados sobre esta forma de discriminação, recorre-se a uma discussão e análise da história e manifestações contemporâneas de anti-semitismo.
\end{abstract}

Palavras-chave: anti-semitismo, Glasgow, Escócia, cidadania global

\section{Introduction}

The aim of this paper is to argue for the inclusion of a knowledge and understanding of religion, religious diversity and the challenges faced by religious minorities in Global Citizenship (Biesta, 2013). The paper uses the example of the Jewish community in the Greater Glasgow Area and in Scotland to illustrate this point, but also to demonstrate that acquiring this knowledge and understanding requires a sophisticated approach that understands the problematic nature of the term anti-Semitism and draws on different sources and may even question some interpretations of the history as written by members of the Jewish community (Collins, 1993; Endelman, 2002; Kushner, 1996; Levy, 1958).

This paper commences with an exploration of Global Citizenship. Global Citizenship, as configured in Scotland, that includes a focus on cultural identity, human rights, diversity and inclusion (Learning and Teaching Scotland, 2011). The paper argues, in accord with the Council of Europe, that religion and religious diversity are key dimensions of national and international society and should be studied to ensure a greater knowledge and understanding of how they impact on the lives of people in contem- 
porary societies. The paper continues with a brief overview of contemporary religious adherence in Scotland as represented in the 2011 national census and explains that the paper will focus on the Jewish community in the Greater Glasgow Area and Scotland (The Scottish Government, 2014). This is followed by a short history of the establishment and development of the Jewish communities in Scotland (Abrams, 2009; Collins, 1993; Levy, 1958; Phillips, 1979). The paper then discusses the problematic nature of the term anti-Semitism; the multifaceted explanation of anti-Semitism of Brustein and King (2004) and the explanation of sectarianism by the European Parliament (2016), (Borowski, 2010; Braber, 2007; Collins, 2008; Kushner, 1996). The paper then examines the narratives of anti-Semitism in Glasgow and Scotland and the "forgotten" history of anti-Semitism and provides an analysis of the major incidences of anti-Semitism, using different dimensions of anti-Semitism. The conclusion concurs with the recent inquiry What's Changed about being Jewish in Scotland? (2016) that "more and better education" about Judaism is required in schools and for adults and this should include a much greater awareness of the extent of historical and contemporary anti-Semitism in the Greater Glasgow Area and Scotland.

\section{Global Citizenship}

There are a number of different ways in which global citizenship can be described. The following explanation from Oxfam is used by charities and organisations focused on school curriculum (IDEAS, 2016). A global citizen is someone who: "is aware of the wider world and has a sense of their own role as a world citizen; respects and values diversity; has an understanding of how the world works; is passionately committed to social justice; participates in the community at a range of levels, from the local to the global; works with others to make the world a more equitable and sustainable place and takes responsibility for their actions" (Oxfam, 1997).

Despite the popularity of the terms, Citizenship education and Global Citizenship, they are contested concepts and have become increasingly problematic. Citizenship has been associated with "membership of an individual to a political community defined within the contours of the Nation-State" (Tawil, 2013). However, there are issues, in some countries, about who legally qualifies for membership and how this impacts on the position of migrants, refugees and the ten million stateless people in the world (UNHRC, 2016). The concept of Global Citizen is contested because citizenship is normally legally configured as membership of a state and not as membership transcending individual states (Tawil, 2013).

\section{Global Citizenship in Scotland}

Global Citizenship is associated with school education in Scotland (by contrast, Intercultural Education is associated with different forms of post-school education). Citizenship and Global Citizenship were introduced as part of the Scottish Curriculum for Excellence in 2004 (Scottish Executive, 2004). The Curriculum for Excellence is "encapsulated" in four capacities that enable a young person to be: a successful learner; a confident individual; a responsible citizen and an effective contributor (Education Scotland, 2016a). A responsible citizen is one who has "respect for others" and has a "commitment to participate responsibly in political, economic, social and cultural life". Two of the capabilities of a responsible citizen are to "develop knowledge and understanding of the world and Scotland's place in it" and "understand different beliefs and cultures". Biesta (2013) points out that, surprisingly, religion is noticeably absent from the core Curriculum for Excellence documents that reference Citizenship or are focused on Citizenship (Learning and Teaching Scotland, 2002; Scottish Executive, 2004).

Citizenship, like the other three capacities, is supposed to be developed through the eight curricular areas in schools (Expressive Arts, Languages, Religious Education, Social Studies, Health and Wellbeing, Mathematics, Sciences and Technologies). Global Citizenship, which is closely connected to Citizenship, is described as being a key context for learning across the Scottish school curriculum (Education Scotland, 2016b). Citizenship and Global Citizenship, then, are not designated as distinct curricular subjects in school education in Scotland. This can be contrasted with the separately funded, governed and structured English school education system (Holt et al., 1999). In England, Citizenship Education was introduced into the National Curriculum in September 2002 (Keating et al., 2010). It became a statutory, discreet and compulsory subject at that time and aims to provide a "high-quality citizenship education (that) helps to provide pupils with knowledge, skills and understanding to prepare them to play a full and active part in society" (Department for Education, 2013).

The positioning of Citizenship and Global Citizenship in the Scottish school curriculum reinforces and promotes the idea that all curriculum areas can contribute to Citizenship and Global Citizenship, and this can be accomplished in an interdisciplinary way. Global citizenship incorporates three main strands: (1) Education for Citizenship; (2) International Development and (3) Sustainable Development (Learning and Teaching Scotland, 2011). The first two strands are of particular importance for this discussion. Education for Citizenship is focused on: "Developing children and young people's sense of rights and res- 
ponsibilities within communities at local, national and global levels" and "fostering informed decision making and the ability to take thoughtful and responsible action, locally and globally". International Development is focused on: "preparing children and young people for life and active participation in a global, multicultural society" and "developing a knowledge and understanding of the world and Scotland's place in it". Global Citizenship is ultimately designed to enhance social literacy and to help young people to gain an understanding of, and critically investigate: cultural identity; human rights; diversity and inclusion (including prejudice and racism).

Learning about cultural identity on a local, national and international scale necessitates a knowledge and understanding of the religious dimensions of cultural identity. On the local level, this is based on the continued, rich historical and contemporary traditions of religious life in Scotland (Houston, 2008; Kenis et al., 2010; McKillop, 2015). On the wider level, this is based on recognition of the worldwide adherence to religious beliefs of many kinds and in the acknowledgement by organisations such as the Council of Europe, in the post 9/11 context, of religious diversity and the importance of including religious education in Intercultural Education in schools in Europe (Council of Europe, 2015; Jackson, 2009; Keast, 2007; Pew Research Center, 2010).

\section{Religion in Scotland}

Historically, religion in Scotland has been almost synonymous with Christianity since the fifth/ sixth centuries up to the mid twentieth century and this has had an important impact on Scottish life, culture and national identity (McCrone, 2001). One of the key moments in this history is the Scottish Reformation in 1560 that rejected Catholicism and, as a result, the Church of Scotland, a Presbyterian Christian denomination rooted in Calvinism, would become the predominant Christian Church (Lynch, 1992). The construction of Scottish national identity was partially formed in the $19^{\text {th }}$ century around the concept of a Presbyterian Protestant people (Robbins, 2000). This was to be challenged by an influx of Irish Roman Catholics fleeing a series of famines in Ireland and dramatically increasing the small local Catholic population (Devine, 2006). This challenge generated some sectarian hostility and, in times of economic depression such as the 1930s, anti-Catholic campaigns (Finn, 2003). There are other Christian denominations in Scotland and also a number of smaller religious minorities, most notably, the Muslims, the Jews, the Hindus, Buddhists and the Sikhs. The national Scottish census of 2011 reported that $53.8 \%$ of the population claimed they belonged to a Christian denomination (The Scottish Government, 2014). The minority religions accounted for a very small percentage of the total population: Muslim (1.4\%); Hindu (0.3\%); Sikh (0.2\%); Buddhist $(0.2 \%)$ and Jewish $(0.1 \%)$.

There has been a decrease in religious adherence in Scotland, as recorded in the 2011 national census compared to the 2001 national census, but there still remains $56.3 \%$ of the population who claim adherence to religion ( $36.7 \%$ claim they have no religion and $7 \%$ did not answer the census question in the 2011 census). There has been an interesting increase, albeit small, in the minority religions; the Jewish community has remained stable. All of these religious groups have a physical and quite vibrant presence in Scotland and contribute to a greater understanding of the complexity and international nature of religious manifestation, belief and practice (Devine, 2006; Maan, 1992). It can be argued that all these religious traditions may be best studied in schools within the context of the curricular area of religious education, but the knowledge and understanding of religious traditions, wherever primarily addressed, should have an interdisciplinary focus that contributes to the process of educating global citizens. One of the challenges for educating global citizens in Scotland is to help young people value diversity, including religious diversity, but also understand the causes and impact of historical and contemporary forms of discrimination. This is equally important for those who are undertaking programmes and courses in Intercultural Education at post-school level.

As has been stated, the majority of the Scottish population (53.8\%) continues to claim some form of adherence to Christianity (The Scottish Government, 2014). While the denominational divisions between Roman Catholics and Protestants have been well documented and well publicized, it is important to explore the inclusion of other minority religious groups, such as the Muslims, the Hindus, the Buddhists, Sikhs and the Jews and the serious challenges they have faced in living in Scotland (Scottish Executive, 2005; The Scottish Government, 2014). This paper will focus on the inclusion of the Jewish community in the Greater Glasgow Area and Scotland and explore some historical and contemporary aspects of anti-Semitism. The Jewish community has been chosen for this study because they have been established much longer than any other religious minority in the $19^{\text {th }}$ to $21^{\text {st }}$ centuries (outwith the Christian denominations) (Abrams, 2009; Collins, 1993; Levy, 1958; Phillips, 1979).

\section{Brief history of the establishment and development of the Jewish communities in Scotland and Glasgow}

It is important to have some understanding of the history of the Jews in Glasgow and Scotland. 
There are accounts of the existence of individual Jews and Jewish families living in Scotland prior to the nineteenth century. There is, however, little evidence of any Jewish communities prior to this date. There were a few academics and teachers who had converted from Judaism and worked in Edinburgh in the seventeenth century (Levy, 1958). There were also a few Jewish tradesmen in Edinburgh in the seventeenth and eighteenth centuries. The first Scottish born Jews to graduate from Scottish Universities were Louis Ashenheim from St Andrews in 1839 and Asher from Glasgow in 1856 (both in medicine) (Collins, 1987). Herman Lyon is noteworthy because he procured a Jewish burial place on the Calton Hill in Edinburgh in the 1790s (Kadish, 2015a). The first recorded Jewish community of twenty families opened a place for worship in Edinburgh in 1816 and moved to larger premises in 1825 (Phillips, 1979). This early community was engaged in the clothing, fur and jewel trades. After a series of moves, a purpose-built synagogue was established in Salisbury Road Edinburgh, in 1932 with a capacity for one thousand people (Kadish, 2015a).

Most of the early history of the Jews in Scotland is focused in Edinburgh and there were other small Jewish communities that were established in Aberdeen, Ayr, Dundee, Dunfermline, Falkirk, Greenock and in the Highlands and Islands (Abrams, 2009; Phillips, 1979). The Jews who settled in Glasgow were to create the largest Jewish community in Scotland. This Jewish community was first established in Glasgow in 1823 by traders and merchants and grew slowly (Collins, 1993; Levy, 1958). The community in Glasgow established a synagogue in the city centre in the 1850 s and opened the first purpose built synagogue in Scotland in Garnethill in 1879 (Collins, 1987). This grand building is described as a Cathedral synagogue, similar to other Cathedral synagogues in Victorian Britain (Kadish, 2015a). The numbers in the Glasgow Jewish community were greatly increased by the arrival of Eastern European migrants in the 1880s. The newcomers who spoke Yiddish settled in the Gorbals, in the south of the city, and increased the Glasgow community from 2,000 in 1891 to 7,000 within a decade (Collins, 2008).

There were tensions between the more established Jews around Garnethill and the incomers in the south side. This tension was possibly due to a combination of a division in social class between the affluent established Jews and the more working class Jews in the south side and a clash of religious culture (Lipman, 1990). The Garnethill synagogue was considered to be an englisher shul by the Jews in the south side - a synagogue for assimilated Jews (Braber, 2007). There was a further influx of Jews into Glasgow from Germany beginning in 1933. These Jews were fleeing the rise of National Socialism and on arrival in Britain were distributed to the cities which had sizeable Jewish communities at that time (Grenville, 2010). There were tensions between the more settled Jews and the new arrivals around national and religious identity and there was a perception that the German Jews were less religious and had compromised their religious identity in favour of their national identity (Alderman, 1998). These tensions eased as the atrocities committed under the "final solution" became more widely publicized and there was a greater understanding of the plight of the German Jewish refugees (Kolmel, 1987).

In the pre-World War II period, over sixty Jewish shops and workshops produced an intense and colourful Jewish street life in the Gorbals (Wasserstein, 1996). There were Jewish bakers, butchers and grocers and Yiddish was spoken in the streets (Devine, 2006). When the Gorbals was redeveloped in the 1960s the Jewish community dispersed throughout the south side of the city and the Greater Glasgow Area (Kenefick, 2013). There are now no Jewish buildings left in the redeveloped Gorbals area (Kadish, 2015b). The vast majority of the Jews in the Greater Glasgow Area are Orthodox (Collins, 2008). In 1931 a Reform congregation was formed in Govanhill in the south side of Glasgow (Braber, 2007). This congregation was small, though the numbers were increased by the arrival of the German Jews in 1933.

The contemporary Jews in Scotland, according to the census of 2011 constitute $6,000(0.1 \%)$ of the population in Scotland and the Jews in Glasgow constitute $897(0.2 \%)$ of the population of the city (Glasgow City Council, 2013; The Scottish Government, 2014). The population of Jews in East Renfrewshire Council area, in the Greater Glasgow Area, is $2,399(2.6 \%)$ of the Council area (East Renfrewshire Council, 2015). The majority of the Jews in Scotland, therefore, are incorporated in the Greater Glasgow Area. There is justified pride about the considerable contribution of members of the Jewish community in local and national politics, Academia, Medicine, Literature and the Arts (Collins, 2008).

\section{Anti-Semitism}

Iganski and Kosmin (2003a: 6-7) argue that the term anti-Semitism has developed from a concept that was originally used to describe a form of racism to a concept that has become a "catch-all" term. This catch-all term now applies to all "bigotry, prejudice and discrimination" towards Jews (Falk, 2008). It is useful, for the purpose of this article to discuss three periods of anti-Semitism: the period from the late $19^{\text {th }}$ century up to the Holocaust; the Holocaust and immediate post-Holocaust period and the period from the 1990s to the present day. There are various popular theories posited for the rise in anti-Semitism prior to the Holocaust. One is 
the modernization thesis that argues that liberalism and capitalism helped to enable the "political, social and economic emancipation of the Jews" leading to a fear of the rise of the power of the Jews (Brustein and King, 2004: 36). Brustein and King (2004) dismiss this theory as it cannot be substantiated across the European states. Another theory is the scapegoat theory: the Jews as minority groups acted as useful scapegoats at times of economic and national crisis. This is discounted on the grounds that other minorities were used as scapegoats and it too cannot be substantiated across the European states. Brustein and King (2004: 38) argue that anti-Semitism should be understood as multifaceted and that this includes recognition of a range of "religious, economic, racial and political prejudice". The second period is the Holocaust and immediate post-Holocaust era, though care must be exercised in the use of the term "Holocaust" as neither the Nazis nor the Jews used this term at the time of the Holocaust. The term Holocaust should not be used synonymously with "Auschwitz" (Bloxham and Kushner, 2005). There are still debates about how the Nazis (and others), during a time of chronic economic depression, were able to translate an ideology of racism against the Jews into a policy of murder and then genocide (Bloxham and Kushner, 2005: 8; Cohn-Sherbok, 2006). The third period is the rise in anti-Semitism in Europe from the 1990s (Iganski and Kosmin, 2003b). Iganski and Kosmin (2003b) make the connection between the rise in anti-Semitism in Britain and events in the Middle East and the reporting of these events in the British media. Incidences of anti-Semitism, for example, increased at the inception of the second Intifada in 2001 and as a result of the Israeli occupation of the West Bank in 2002.

The rise in anti-Semitism across Europe, in recent years, has been monitored by the European Parliament and the Parliament has produced the following detailed working definition: "Anti-Semitism is a certain perception of Jews, which may be expressed as hatred towards Jews. Rhetorical and physical manifestations of anti-Semitism are directed towards Jewish or non-Jewish individuals and/or their property, toward Jewish community institutions and religious facilities" (European Parliament, 2016). Anti-Semitism can be expressed in "speech, writing, visual forms and action and employs sinister stereotypes and negative character traits". The European Parliament provides a very useful list of examples of anti-Semitism which can be accessed at http://www.antisem.eu/projects/eumc-working-definition-of-antisemitism/. This includes examples that involve forms of racist, religious, political, economic and societal discrimination, Holocaust denial or accusations of Holocaust exaggeration.

The European Parliament does acknowledge that there can be valid criticism of the state of Israel that is not anti-Semitic: "criticism of Israel similar to that leveled against any other country cannot be regarded as anti-Semitic".

The academic discussion about the breadth of the term anti-Semitism (Iganski and Kosmin, 2003a) and the multifaceted nature of the term (Brustein and King, 2004) and the diverse examples provided by the European Parliament help to explain the serious challenges that are faced in the analysis of incidences of anti-Semitism.

\section{Narratives of anti-Semitism in Glasgow and Scotland}

There have been a number of interesting approaches to the issue of anti-Semitism in the literature about the history of the Jewish community in Glasgow and the wider Jewish community in Scotland - as written by members of the Jewish community or by those associated with the community. A common approach adopted by Jewish writers is to highlight the lack of concerted anti-Semitic activity in the history of Jews in Scotland and compare this with other parts of the UK and Europe. This approach is favoured in academic and literary accounts such as those by Levy (1958), Daiches $(1957 ; 1977)$ and Glasser (1986). Levy, for example, in 1958 stated: "It has been truly said that Jews have never been persecuted in Scotland - and that can be said of few other countries with a long history..." (1958: 9). Abrams concurs fifty years later in 2009: "In general, unlike most other European countries, Scotland has had a good record of tolerance towards Jews, and a lack of anti-Semitism. This was especially true outside of Glasgow and Edinburgh" (2009: 82). Collins (2008) and Borowski (2010) are in accord with these views. However, they also comment (with Abrams) on an increase of incidents of anti-Semitism since the 1960s, which has intensified as a result of tensions in the Middle East.

There are very few historical incidences of anti-Semitism reported in the literature discussed above and these incidences appear to support and confirm the narratives that have been developed. It is reported that some bowling clubs and golf clubs in the Greater Glasgow Area would not admit Jewish members in the 1920s and beyond this period, prompting the establishment of a Jewish golf club in 1928 (Devine, 2006). Similarly, there are very few reported incidents of anti-Semitism in the Ayr community and the small community in Greenock was well integrated into the local community. In Aberdeen, in the 1980s, there were attempts to block both the twinning between the University of Aberdeen and a University on the West Bank and the visit of an Israeli delegation (Abrams, 2009). There were further minor incidents, and in the early 2000s, there was an increase of anti-Semitic activity 
caused by the conflict between the Israelis and the Palestinians, though, there is no record of physical violence towards the Jewish community in Aberdeen. Abrams notes that there has been a series of anti-Zionist (non-acceptance of, and denial of legitimacy of, Jewish nationhood) and anti-Semitic incidents in Dundee since the 1960s that have led to the dwindling of the Jewish community (Alderman, 2002).

Abrams (2009) argues that the low levels of anti-Semitism and very low levels of serious anti-Semitism in Scotland can be accounted for by the respect of the Scottish Protestants for the Hebrew Bible and the "people of the book". Other reasons for the historical low levels of anti-Semitism may be that the Jews did not compete for semi-skilled and unskilled jobs but created their own employment such as tailoring and peddling (Devine, 2006). The Jewish community also relied on their own social welfare provided by the Jewish Board of Guardians and other agencies so that new arrival Jews in the Gorbals would not be a burden on public relief (Collins, 1990). The history of religious discrimination in Scotland, from the nineteenth century, is dominated by the sectarian strife between Protestants and Roman Catholics (Robbins, 2000). This has been marked by periods of explicit sectarian discrimination towards Catholics by the Church of Scotland in the 1920s, anti-Catholic demonstrations in the 1930s and the continuation of hostility through football rivalry and marches and parades (Forrester, 1999; Murray, 2000; The Scottish Government, 2015). The Jews were much smaller in number than the Roman Catholic community and posed less of a threat. Further, any incidences of anti-Semitism were not on the same scale and intensity of the sectarian dispute and were not as sustained. The Jews in Glasgow, concentrated in the Gorbals until the 1960s, appeared to have a good relationship with the large Roman Catholic community living there (Glasser, 1986).

Collins (2008) states that the contemporary Jewish community in Scotland is sensitive to anti-Semitism, collective criticism of Jews and stereotyping of Jews. He points out that media reports about the Middle East can provide an impetus for anti-Semitism and there can be a conflation of Israel and Jewish. This means that attacks on Jews in Scotland are motivated by anger about events in Israel or events that are Israel-related. This is exemplified in the defacing of Garnethill synagogue with the words, "Hizbollah" in 2006 as part of a reaction in different parts of the world towards deaths in Lebanon (Herald, 2006; World Jewish Congress, 2006). The public visibility of distinctive Jewish buildings, such as the Jewish shops in the Gorbals and the impressive purpose-built synagogues in Garnethill and Giffnock were signs of the numerical growth and confidence of the Jewish community and symbolized the physical presence of the Jewish community. Ironically, they also provide easily identified and accessible targets for anti-Semitic activity, such as those in 1947 and 2006. The attacks on Jewish buildings appear to be motived by the religious and economic dimensions of anti-Semitism.

Other recent reports of intimidating behavior towards Jews in Glasgow, mirroring anti-Semitic behavior in other parts of Europe, have been prompted by events in Israel and Palestine (Garavelli, 2015). These recent attacks are consistent with some of the examples raised by the European Parliament (2016): "Accusing Jews as a people of being responsible for real or imagined wrongdoing committed by a single Jewish person or group..." and "Holding Jews collectively responsible for actions of the state of Israel". This is not to deny the right to engage in legitimate criticism of the state of Israel or a serving government in Israel, as articulated by the European Parliament (2016), but to reject any criticism that is anti-Semitic.

A spike in anti-Semitic incidents in August 2014 prompted by the conflict in Gaza provided the impetus for the Scottish Council of Jewish Communities to conduct a government funded, small scale inquiry into the experience of being Jewish in Scotland: What's Changed about being Jewish in Scotland? (2016) (Frank et al., 2016; Mason, 2016). This was a follow-up to a previous survey, Being Jewish in Scotland in 2012 (Frank et al., 2013). The findings of the 2016 inquiry are disturbing and reflect a serious disquiet in the sample including: anxieties about being identified as Jewish; keeping Jewish identity quiet; the negative effects of the events in the Middle East in 2014; the pro-Palestine stance adopted by some Scottish Councils; the rise in anti-Semitism through social media; a lack of confidence in the impartiality of public authorities (including the Police) and some participants in the inquiry were even considering leaving Scotland for the first time. This rise in anti-Semitism appears to represent a new development in the history of the Jews in the Greater Glasgow Area and in Scotland.

\section{The "forgotten" history of anti-Semitism in Scotland}

At this point it is instructive to revisit the history of the Jews in the Greater Glasgow Area and Scotland and the issue of inclusion and anti-Semitism. This revisiting probes the history more deeply, and draw on the additional accounts of historians who are not affiliated to the Jewish community in Scotland. There are a number of key incidences of anti-Semitism in the Greater Glasgow Area that merit close attention. The German Jews who arrived in Scotland in the late 1930s, fleeing the rise of National Socialism, were to experience discrimination in Scotland at the outbreak of the Second World War (Kolmel, 1987). 
These experiences have received little attention in the "narratives" of anti-Semitism in Scotland. Kolmel (1987: 67) explains these experiences as the result of a "widespread failure" to differentiate between the German Jews and the National Socialist Germans. Some of the German Jewish refugees in Scotland lost their jobs at this time and others concealed their identity. Kolmel's analysis, however, is open to challenge, as it does not fully contextualize these experiences within the rise in anti-Semitism across Europe prior to the Holocaust that may have contributed to the motivation for this combination of the racist and religious dimensions of anti-Semitism (Brustein and King, 2004). This also contributed to another less well-known set of negative experiences for Jews in Glasgow: at the beginning of the Second World War there was vandalism of Jewish shops and properties in Glasgow (Braber, 2007).

There were to be more serious incidences of anti-Semitism in Glasgow in the summer of 1947. The Irgun organization, a Jewish terrorist group, kidnapped two British army sergeants in Palestine. In an act of retaliation for the hanging of three Irgun men, the two British soldiers were hanged and their bodies were booby-trapped. This prompted anti-Jewish riots in many British cities, including Liverpool, Manchester, London and Glasgow (Endelman, 2002). This disruption began in Liverpool on the first of August and spread to Glasgow on the second of August (Kushner, 1996). Jewish shops in the Gorbals were attacked and on the third of August a Jewish shopkeeper in the Gorbals was beaten up. The disruption dissipated by the end of the week and there was fairly widespread condemnation of this unruly behavior. Deeper public understanding of the full horror of the Holocaust, the new relationship between Britain and the new Jewish state and welcome economic recovery brought an end to this anti-Semitic activity.

It is difficult to fully comprehend the motives behind these attacks. The bombing of the King David Hotel in Jerusalem in 1946 resulted in the death of ninety-one people including many from Britain and this major act of terrorism did not prompt rioting in Britain (Kushner, 1996). By 1947 the effects of the economic depression had become more widespread and there was an underlying perception that Jews had exploited the war economically while not participating in the military effort. Kushner (1996: 158) points out that the reality was that the Jewish participation in the war was disproportionate to their numbers, but the erroneous and damaging perception persisted and is an example of the economic dimension of anti-Semitism.

There is evidence that a good proportion of the rioters in Glasgow (and Liverpool) were people who were unemployed; the two cities experiencing the highest levels of unemployment in Britain at that time. Further, the British Empire was diminishing and new, more insular ways of understanding Britain and Britishness were emerging. This period of unrest may also have reflected tensions surrounding identity and a perception that the Jews, despite most of them being born in Britain, were outsiders, even foreigners. This is an example of the racist dimension of anti-Semitism. One of the effects of this period was that the Jewish communities affected by the riots adopted a low profile (Kushner, 1996: 162). According to Kushner (1996: 165-166), there has been a process of "collective forgetting" about this period within the Jewish community and these events in Glasgow receive little attention in the literature.

\section{Conclusion}

The incidents recounted above demonstrate that anti-Semitism in the Greater Glasgow Area and in Scotland is a complex historical and contemporary problem. There may not have been persecution and concerted anti-Semitic activity over a period of time and there may not be many examples of personal violence (Levy, 1958). Nevertheless, there were some serious incidents that are not widely reported or have been "forgotten", which have been recovered by historians and create a fuller narrative. Further, while there are some patterns that can be discerned in the manifestations of anti-Semitism in Scotland, the historical and contemporary evidence appears to support the complex and multifaceted anti-Semitism advocated by Brustein and King (2004), the pluriformity of examples offered by the European Parliament, and confirms the problematic nature of the term anti-Semitism (Iganski and Kosmin, 2003a; Falk, 2004).

One of the interesting points for action for public bodies in the recent What's Changed about being Jewish in Scotland? (Frank et al., 2016: 28), is "more and better education about Judaism and other religions in schools and for the general public". Another point of action for the Jewish community and Jewish communal organisations is: "training younger volunteers to speak about Judaism in schools and to community groups". It would be important in both action points to focus on "better" education in schools and for the general public, because a better education would incorporate a more complete and nuanced knowledge and understanding of the history and contemporary manifestations of anti-Semitism in Scotland. This would be rooted in a greater comprehension of anti-Semitism, the problematic nature of the term anti-Semitism, and of the different dimensions of anti-Semitism that are most applicable to Scotland. This "better" education in Judaism would be an important part of the education of young people in Scotland to be global citizens. It would provide insight into the Jewish 
community in Scotland and also the wider global Jewish community and help their understanding and critical investigation of cultural identity, diversity and inclusion.

\section{References}

ABRAMS, N. (2009), Caledonian Jews: A Study of Seven Small Communities in Scotland, Jefferson, McFarland and Company.

ALDERMAN, G. (1998), Modern British Jewry, Oxford, Clarendon Press.

ALDERMAN, G. (2002), "The Tradition of Left-Wing Anti-Jewish Prejudice in Britain", in P. Iganski e B. Kosmin (eds.), A New Antisemitism? Debating Judeophobia in 21 $1^{\text {st }}$-Century Britain, London, Profile Books.

BIESTA, G. (2013), "Citizenship Education", in T.G.K. Bryce and W.M. Humes (eds.), Scottish Education, Edinburgh, Edinburgh University Press.

BLOXHAM, D. and T. Kushner (2005), The Holocaust. Critical Historical Approaches, Manchester, Manchester University Press.

BOROWSKI, E. (2010), "Scotland's Jews: Community and Political Challenges", Jerusalem Center for Public Affairs.

http://jcpa.org/article/scotlands-jews-community-and-political-challenges-2/

BRABER, B. (2007), Jews in Glasgow 1879-1939, London, Vallentine Mitchell.

BRUSTEIN, W.J. and R.D. King (2004), "Anti-Semitism before the Holocaust", International Political Science Review, 25 (1), pp. 35-53.

COHN-SHERBOK, D. (2006), The Paradox of Anti-Semitism, London, Continuum.

COLLINS, K. E. (1987), "The Growth and Development of Scottish Jewry 1880-1940", Aspects of Scottish Jewry, Glasgow, Glasgow Representative Council, pp. 3-9.

COLLINS, K. E. (1990), Second City Jewry, Glasgow, Scottish Jewish Archives.

COLLINS, K. E. (1993), Glasgow Jewry: A Guide to the History and Community of the Jews in Glasgow, Glasgow, Scottish Jewish Archives Committee.

COLLINS, K.E. (2008), Scotland's Jews. A Guide to the History and Community of the Jews in Scotland, Glasgow, Scottish Council of Jewish Communities.

DAICHES, D. (1957), Two Worlds, Edinburgh, Canongate Publishing Limited.

DAICHES, D. (1977), Glasgow, St Alban's, Granada Publishing.

DEVINE, T.M. (2006), The Scottish Nation 1700-2000, London, Penguin Books.

ENDELMAN, T.M. (2002), The Jews of Britain 1656 to 2000, Berkeley, University of California Press.
FALK, A. (2008), Anti-Semitism: A History and Psychoanalysis of Contemporary Hatred, Westport, Praeger Publishers.

FINN, G.P.T. (2003), "Sectarianism", in T.G.K. Bryce and W.M. Humes (eds.), Scottish Education Post-devolution, Edinburgh, Edinburgh University Press.

FORRESTER, D.B. (1999), "Ecclesia Scoticana - Established, Free or National?", Theology, 102, pp. 80-89.

FRANK, F.; E. Borowski and L. Granat (2013), Being Jewish in Scotland, Glasgow, The Scottish Council of Jewish Communities.

http://www.scojec.org/resources/files/bjis.pdf

FRANK, F.; E. Borowski; L. Granat and R. Hounsom (2016), What's Changed about Being Jewish in Scotland?, Glasgow, The Scottish Council of Jewish Communities.

http://www.scojec.org/resources/files/bjis2.pdf

GARAVELLI, D. (2015), "Growing Anti-Semitism in Scotland", The Scotsman, 22 February.

GLASSER, R, (1986), Growing up in the Gorbals, London, Chatto \& Windus Ltd.

GRENVILLE, A. (2010), Jewish Refugees from Germany and Austria in Britain 1933-1970, London, Vallentine Mitchell.

HERALD (2006), "Jewish Community Shocked by Vandalism at Synagogue", 2 August. http://www. heraldscotland.com/news/12426264.Jewish_community_shocked_by_vandalism_at_synagogue_SCOTLAND/

HOLT G.; S. Boyd; B. Dickinson; J. Loose and S. O'Donnell (1999), Education in England, Wales and Northern Ireland, Slough, National Foundation for Educational Research.

HOUSTON, R. (2008), Scotland: A Very Short Introduction, Oxford, Oxford University Press.

IGANSKI, P. and B. Kosmin (2003a), "The New Anti-Semitism Debate: Background and Context", in P. Iganski e B. Kosmin (eds.), A New Antisemitism? Debating Judeophobia in $21^{\text {st }}$-Century Britain, London, Profile Books.

IGANSKI, P. and B. Kosmin (2003b), "Globalized Judeophobia and its Ramifications for British Society", in P. Iganski e B. Kosmin (eds.), A New Antisemitism? Debating Judeophobia in 21st-Century Britain, London, Profile Books.

JACKSON, R. (2009), "The Council of Europe and Education about Religious Diversity", British Journal of Religious Education, 31 (2), pp. 85-90.

KADISH, S. (2015a), "Jewish Heritage in Scotland", Jewish Historical Studies, 47, pp. 179-216.

KADISH, S. (2015b), Jewish Heritage in Britain and Ireland, Belgium, Historic England.

KEAST, J. (2007), Religious Diversity and Intercultural Education: A Reference Book for Schools, Council of Europe.

KEATING, A.; D. Kerr; T. Benton; E. Mundy and J. Lopes (2010), "Citizenship Education in England 2001-2010: Young People's Practices and Prospects for the Future: 
The Eighth and Final Report from the Citizenship Education Longitudinal Study (CELS)", Research Report DFE-RR059, Department for Education.

https://www.gov.uk/government/uploads/system/ uploads/attachment_data/file/181797/DFE-RR059.pdf

KENEFICK, (2013), "The Jews and Irish in Modern Scotland: Anti-Semitism, Sectarianism and Social Mobility", Immigrants and Minorities, 31 (2), pp. 189-213.

KENIS, L.; J. Billiet and P. Pasture (eds.) (2010), The Transformation of the Christian Church in Western Europe 1945-2000, Leuven, Leuven University Press.

KOLMEL, R. (1987), "German-Jewish Refugees in Scotland", Aspects of Scottish Jewry, Glasgow, Glasgow Representative Council, pp. 57-84.

KUSHNER, T. (1996), "Anti-Semitism and Austerity: The August 1947 Riots in Britain", in P. Panayi (eds.), Racial Violence in Britain in the Nineteenth and Twentieth Centuries, London, Leicester University Press.

LEARNING AND TEACHING SCOTLAND (2011), "Developing Global Citizens within Curriculum for Excellence", Glasgow, Learning and Teaching Scotland.

LEVY, A. (1958), The Origins of Scottish Jewry, Jewish Historical Society of England.

LIPMAN, V.D. (1990), A History of the Jews in Britain since 1858, Leicester, Leicester University Press.

LYNCH, M. (1992), Scotland: A New History. London, Pimlico.

MAAN, B (1992), The New Scots, Edinburgh, John Donald Publishers Ltd.

MASON, C. (2016), "Scottish Jews 'afraid' to Lead Lives in Scotland", The Scotsman, 3 August.

MCCRONE, D. (2001), Understanding Scotland. The Sociology of a Nation, London, Routledge.

MCKILLOP, A. (2015), "The Blithe Assumption that Scotland is a Post-Christian Country", Scottish Review, 7 May.

http://www.scottishreview.net/AlasdairMcKillop155. shtml

MURRAY, D.M. (2000), Rebuilding the Kirk. Presbyterian Reunion in Scotland 1909-1929, Edinburgh, Scottish Academic Press.

OXFAM (1997), What is Global Citizenship?, Oxford, Oxfam.

PHILLIPS, A. (1979), A History of the Origins of the First Jewish Community in Scotland - Edinburgh 1816, Edinburgh, John Donald.

ROBBINS, K. (2000), "Establishing Disestablishment: Some Reflections on Wales and Scotland", in S.J. Brown and G. Newlands (eds.), Scottish Christianity in the Modern World. Edinburgh, T \& T Clark.

SCOTTISH EXECUTIVE (2004), "A Curriculum for Excellence", Edinburgh, Scottish Executive.
WASSERSTEIN, B. (1996), Vanishing Diaspora: The Jews in Europe since 1945, London, Hamish Hamilton.

\section{Institutional Links}

COUNCIL OF EUROPE (2015), "Compass: Manual for Human Rights Education with Young People", Religion and Belief, Council of Europe.

http://www.coe.int/en/web/compass/religion-and-belief

DEPARTMENT OF EDUCATION (2013), Statutory Guidance National Curriculum in England: Citizenship Programmes of Study for Key Stages 3 and 4.

https://www.gov.uk/government/uploads/system/ uploads/attachment_data/file/181797/DFE-RR059.pdf

EAST RENFREWSHIRE COUNCIL (2015), Planning for the Future of East Renfrewshire.

http://www.eastrenfrewshire.gov.uk/CHttpHandler. ashx?id $=11766 \& p=0$

EDUCATION SCOTLAND (2016a), The Purpose of the Curriculum.

http://www.educationscotland.gov.uk/learningandteaching/thecurriculum/whatiscurriculumforexcellence/thepurposeofthecurriculum/index.asp

EDUCATION SCOTLAND (2016b), Global Citizenship.

http://www.educationscotland.gov.uk/learningandteaching/learningacrossthecurriculum/themesacrosslearning/globalcitizenship/

EUROPEAN PARLIAMENT WORKING GROUP ON ANTISEMITISM (2016), Working Definition of Antisemitism.

http://www.antisem.eu/projects/eumc-working-definition-of-antisemitism/

GLASGOW CITY COUNCIL (2013), "Briefing Paper 2011 Census - Release 2A - results for Glasgow City", Glasgow City Council.

http://www.glasgow.gov.uk/chttphandler.ashx?id=16943 IDEAS (2016), "What is Global Citizenship?", IDEAS.

http://www.ideas-forum.org.uk/about-us/global-citizenship

LEARNING AND TEACHING SCOTLAND (2002), "Education for Citizenship in Scotland", Learning and teaching Scotland.

http://www.educationscotland.gov.uk/resources/e/ genericresource_tcm4637863.asp

PEW RESEARCH CENTER (2010), "The Global Religious Landscape".

http://www.pewforum.org/2012/12/18/global-religious-landscape-exec/

SCOTTISH EXECUTIVE (2005), "Record of the Discussion of the Summit on Sectarianism Held on 14 February 2005", Edinburgh, Scottish Executive.

http://www.scotland.gov.uk/Publications/2005/04 /2193329/33313

TAWIL, S. (2013), "Education for 'Global Citizenship': A Framework for Discussion", ERF Working Papers, n. 0 7, UNESCO Education Research and Foresight. 
THE SCOTTISH GOVERNMENT (2014), "Summary: Religious Group Demographics", Scottish Government.

http://www.gov.scot/Topics/People/Equality/Equalities/ DataGrid/Religion/RelPopMig

THE SCOTTISH GOVERNMENT (2015), "Tackling Sectarianism and its Consequences in Scotland", Final Report of the Advisory Group on Tackling Sectarianism in Scotland - April 2015.
http://www.gov.scot/Publications/2015/05/4296 UNHRC (2016), "Ending Statelessness", UNHRC. http://www.unhcr.org/uk/stateless-people.html WORLD JEWISH CONGRESS (2006), "Attacks on Synagogues around the World", 2 August.

http://www.worldjewishcongress.org/en/news/attacks-on-synagogues-around-the-world

Recebido a 12/08/2016. Aceite para publicação a 15/11/2016.

Stephen McKinney (stephen.mckinney@glasgow.ac.uk). University of Glasgow, School of Education, Creativity, Culture and Faith (Research and Teaching Group). 11 Eldon Street, Glasgow G3 6NH, Scotland. 